\title{
Renal and immunological effects of occupational exposure to inorganic mercury
}

\author{
S Langworth, C G Elinder, K G Sundquist, O Vesterberg
}

\begin{abstract}
Seven parameters of renal dysfunction (urinary excretion of albumin, orosomucoid, $\boldsymbol{\beta}_{2}-$ microglobulin, $\mathbf{N}$-acetyl- $\boldsymbol{\beta}$-glucosaminidase (NAG), and copper; serum creatinine concentration, and relative clearance of $\beta_{2}-$ microglobulin) were examined in a group of chloralkali workers exposed to mercury vapour $(n=89)$ and in an unexposed control group $(n=75)$. Serum concentrations of immunoglobulins (IgA, IgG, IgM) and autoantibodies towards glomeruli and other tissues were also determined. The parameters examined were compared between the two groups and related to different exposure parameters. In the chloralkali group median blood mercury concentration (B-Hg) was 55 nmol/1, serum mercury (S-Hg) $45 \mathrm{nmol} / 1$, and urine mercury concentration (U-Hg) 14.3 nmol/mmol creatinine $(25 \cdot 4 \mu \mathrm{g} / \mathrm{g}$ creatinine). Corresponding concentrations for the control group were $15 \mathrm{nmol} / \mathrm{l}, 4 \mathrm{nmol} / 1$, and $1.1 \mathrm{nmol} /$ mmol creatinine (1.9 $\mu \mathrm{g} / \mathrm{g}$ creatinine) respectively. None of the parameters of renal dysfunction differed significantly between the two groups, but there was a tendency to increased excretion of NAG in the exposed group compared with the controls. Also, a statistically significant relation existed between $\mathrm{U}-\mathrm{Hg}$ and U-NAG ( $<<0.001)$. Serum immunoglobulin concentrations did not differ between the groups, and serum titres of autoantibodies (including antiglomerular basement membrane and antilaminin antibodies) were low in
\end{abstract}

Department of Occupational Medicine, Huddinge Hospital, S-141 86 Huddinge, Sweden

$S$ Langworth

Department of Medicine, Renal Section, Karolinska Hospital, S-104 01 Stockholm, Sweden

C G Elinder

Department of Clinical Immunology, Huddinge Hospital, S-141 86 Huddinge, Sweden

K G Sundquist

Division of Medical Chemistry, National Institute of Occupational Health, S-171 84 Solna, Sweden

O Vesterberg both groups. Thus the results gave no evidence of glomerular damage or of a tubular reabsorption defect at the current relatively low exposures. The findings still indicate slight, dose related tubular cell damage in the mercury exposed group. There were no signs of a mercury induced effect on the immune system.

It is well known that inorganic mercury compounds may cause both glomerular and tubular damage. ${ }^{1}$ Glomerular damage with nephrotic syndrome after exposure to mercury has been described in case reports $^{2-4}$ and animal studies suggest that immunological mechanisms are involved in the aetiology of this glomerular injury. ${ }^{5-7}$ Increased prevalence of antilaminin antibodies has been reported $^{8}$ among workers exposed to mercury in Belgium, but this finding was not confirmed in a later study.

The tubular damage is considered to result from toxic effects of mercury accumulated in the distal and middle portions of the proximal tubuli. ${ }^{1}$ If glomerular damage develops parallel to this, the resorption of filtered, protein bound mercury may cause pronounced tubular necrosis. ${ }^{1011}$

Increased urinary excretion of high molecular weight proteins, indicating glomerular dysfunction, has been related to occupational exposure to mercury in several studies. ${ }^{12-14}$ Tubular damage is often monitored by measurements of smaller urinary proteins such as $\beta_{2}$-microglobulin or retinol binding protein (RBP), and of tubular enzymes. ${ }^{15}{ }^{16}$ Only a few studies of workers exposed to mercury have shown increased excretion of small proteins, suggesting tubular damage, whereas several authors have related the activities of certain lysosomal enzymes in urine to exposure to mercury. ${ }^{14}{ }^{17-20}$

The purpose of the present study was to compare renal function in a group of chloralkali workers exposed to mercury with that of an unexposed control group, and to study the relation between different dose indicators and the selected indicators of renal dysfunction. Also, a possible mercury induced humoral immune response was examined by determination of circulating immunoglobulins (IgA, IgG, IgM) and autoantibodies towards glomeruli and other tissues. 


\section{Subjects}

The study population was composed of a mercury exposed group of chloralkali workers from five plants, and a control group of industrial workers (not occupationally exposed to mercury) from two chemical industries, a paper works, and a sawmill. A total of 96 chloralkali workers and 80 unexposed workers were asked to take part in the study on a voluntary basis. Workers supposed to have high exposure to mercury were asked to participate first, as the object of the study was to detect renal damage induced by mercury. The exposed and control groups were comparable in age and type of work. Exposure to other heavy metals (for example, lead, cadmium), organic solvents, or excessive alcohol intake were criteria for exclusion.

The mercury exposed group comprised 89 workers (93\% participation rate) with a mean age of $42 \cdot 7$ (SD $12.7)$ years. Their duration of exposure varied between one and 45 (mean 13.5 (SD 8.7)) years. The definitive control group consisted of 75 workers (94\% participation rate) with mean age 43.6 (SD $12.5)$ years. For more details about the study population see Langworth et al. ${ }^{21}$

Among the exposed workers there were eight subjects with hypertension (four treated with diuretics and four treated with $\beta$-blocking agents), two with orally treated diabetes (type II diabetes), one with earlier history of renal stones, and one with suspected earlier pyelitis. Corresponding figures in the control group were: seven with hypertension (two treated with diuretics and five with $\beta$-blocking agents), one with orally treated type II diabetes, four with earlier renal stones, and one with suspected earlier pyelitis. In the statistical analyses the material was examined both in total and after elimination of individual subjects with the diseases mentioned.

\section{Methods}

All subjects underwent a routine clinical examination by a physician, including an interview focused on history of exposure and previous health state. In the chloralkali group, data from routine blood mercury controls during the past five years, and detailed information about the person's work exposure were collected from each company's health care unit. Data on smoking (smoker or not), intake of alcohol (average weekly intake of beer, wine, spirits) and consumption of fish (number of fish meals a week and type of fish eaten), were registered by a questionnaire and checked at the interview. Odontological state was recorded by a dentist. The total number of amalgam fillings, the number of amalgam surfaces of each filling (0-5), and the number of gold fillings were registered.

Blood and urine samples were collected on the same day as the physical examination. Samples for whole blood mercury analysis were collected in metal free, heparinised Venoject tubes (Terumo Europe NV, Leuven, Belgium) and serum samples for mercury analysis were collected in metal free Venoject tubes, which were centrifuged one hour after sampling to separate the blood cells. Morning urine samples were collected at home by each subject in 250 $\mathrm{ml}$, acid washed, polyethylene bottles and delivered to the company's health care units where the urine was immediately examined with a test stick for $\mathrm{pH}$, sugar, proteins, red blood cells, and bacteria (Boehringer Nephur-Test ${ }^{R}$, Mannheim, Germany). Urine samples with $\mathrm{pH}$ below 6 were tested for $\mathrm{pH}$ with a special test stick (Merck Spezialindikator $\mathrm{pH}$ 4.0-7.0, E Merck, Darmstadt, Germany). All samples were then poured into $12 \mathrm{ml}$ metal free, plastic tubes, frozen, and stored at $-20^{\circ} \mathrm{C}$.

The selected indicators of renal dysfunction were: (a) urinary albumin concentration (U-albumin), (b) urinary orosomucoid concentration (U-orosomucoid), (c) urinary $\beta_{2}$-microglobulin concentration (U- $\beta_{2}$ ), (d) urinary $\mathrm{N}$-acetyl- $\beta$-D-glucosaminidase activity (U-NAG), (e) urinary copper (U-Cu) concentration, ( $f$ ) creatinine concentration in serum (S-creatinine), and (g) relative clearance of $\boldsymbol{\beta}_{2}$ microglobulin.

Urinary albumin and orosumucoid concentrations were determined by zone immunoelectrophoresis assay (ZIA). ${ }^{22}$ Antibodies were from Dako, Copenhagen, Denmark, and Seronorm protein (Nycomed, Oslo, Norway) was used as standard. $\beta_{2}-$ Microglobulin was quantified in urine and serum by radioimmunoassay (Phadebas $\beta_{2}$-microtest kit, Pharmacia, Uppsala, Sweden). Urine samples with pH below 5.6 were not analysed for $\beta_{2}$-microglobulin ( $n=11$ in the exposed group and $n=13$ in the control group). After centrifugation and gel filtration of the urine samples on Sephadex G50 (Pharmacia, Sweden) to remove interference NAG activity in urine was determined colorimetrically. ${ }^{23}$ Creatinine concentrations in urine and serum were measured with Jaffe's colorimetric method using picric acid and a reaction rate analyser (LKB 8600, Diagnostica, Boehringer-Mannheim GMBH, Germany). The copper concentration in urine was determined with electrothermal atomic absorption spectrophotometry (ETAAS) using the Perkin-Elmer Zeeman/ 3030 system, which comprised a microcomputer controlled spectrometer, a HGA-600 graphite furnace with an AC-Zeeman magnet, an AS-60 autosampler, and a PR-100 printer. Each sample was analysed in duplicate. In a sequence of 10 samples with a mean concentration of $24.6 \mu \mathrm{g} / 1$ the standard deviation (SD) was $1.0 \mu \mathrm{g} / \mathrm{l}$, and the coefficient of variation $(\mathrm{CV})$ was $4 \%$. Relative clearance $(\mathrm{Cl})$ of $\beta_{2}$ microglobulin $\left(\beta_{2}\right)$ was calculated according to the formula: ${ }^{24}$

$$
\text { Cl } \beta_{2} / \mathrm{Cl} \text { creatinine }(\%)=100 \times \frac{\mathrm{U}-\beta_{2} \times \mathrm{S} \text {-creatinine }}{\mathrm{S}-\beta_{2} \times \mathrm{U} \text {-creatinine }}
$$


Serum concentrations of immunoglobulins (IgA, IgG, IgM) were determined by nephelometry and serum titres of autoantibodies to reticulin, smooth muscle, parietal cells, mitochondria, cell nuclei, and glomeruli were measured by an indirect immunofluorescence test. ${ }^{25}$ Specific antibodies to glomerular basement membrane antigen (anti-GBM) were determined by an "anti-Goodpasture" enzyme immunoassay from Biocarb Diagnostics AB, Lund, Sweden. Antilaminin antibodies were determined by an ELISA technique. ${ }^{26}$ Ninety six well Costar microwell titration plates were coated by laminin (Sigma Catalogue No L-2020) at a concentration of $10 \mu \mathrm{g} / \mathrm{ml}$ at $4^{\circ} \mathrm{C}$ overnight. After five washes in PBS (phosphate buffered saline), the plates were blocked for 20 hours by PBS containing $1 \%$ FCS (fetal calf serum) and $0.02 \%$ sodium azide. The plates were then washed three times in PBS and incubated for 20 hours at $4^{\circ} \mathrm{C}$ with a mouse monoclonal antilaminin antibody (Boehringer-Mannheim, Germany) or with serum diluted 1:100. After three washes in PBS the plates were incubated with alkaline phosphatase conjugated antibodies to human and mouse immunoglobulins respectively. The plates were finally washed three times and incubated with substrate (diethanolamine). The optical density was then read in a Bio TEK microplate EL 309 spectrophotometer at $405 \mathrm{~nm}$.

Total mercury concentrations in whole blood (B$\mathrm{Hg})$, serum $(\mathrm{S}-\mathrm{Hg})$, and urine $(\mathrm{U}-\mathrm{Hg})$ were analysed in the laboratory of the Division of Medical Chemistry at the Swedish National Institute of Occupational Health. A modified version of the cold vapour atomic absorption spectrophotometry technique was used. ${ }^{27}{ }^{28}$ For further details concerning quality control of the mercury analyses see Langworth et al. ${ }^{21}$

The urinary excretions of mercury, proteins, NAG, and copper were adjusted for excretion of creatinine.

Within the mercury exposed group the renal dysfunction parameters were related to five different exposure indicators: (1) current $\mathrm{B}-\mathrm{Hg}, \mathrm{S}-\mathrm{Hg}$, and $\mathrm{U}-$ $\mathrm{Hg}$; (2) duration of exposure (number of work-years at the chloralkali plant); (3) intensity of exposure (low, medium, or high mercury exposure, based on the employees type of work and their expected exposure to mercury judged by one of the researchers and the company doctors); (4) consumption of fish (number of fish meals a week and type of fish); (5) amalgam burden (estimated as $0-5$ amalgam surfaces for each tooth with amalgam fillings). In the control group the parameters of renal dysfunction were related to the exposure indicators 1,4 , and 5 . Fish consumption and amalgam burden were included as indicators of background exposure to methylmercury and inorganic mercury respectively.

STATISTICAL ANALYSIS

Comparisons of the examined parameters (renal dysfunction parameters, immunoglobulins, and autoantibodies in serum) between the exposed and the control groups were made with Student's $t$ test or the Mann-Whitney rank sum test (for skewed parameters). Dose-effect relations were studied with Pearson's correlation coefficient or with Spearman's rank correlation coefficient (for skewed parameters). In both groups the influence of age, smoking, and alcohol intake was examined by multiple regression and by analysis of variance (ANOVA).

The 90th percentiles of the parameters of renal dysfunction in the control group were regarded as upper normal and values above these among the exposed workers were considered as abnormal. The prevalence of abnormal values of the dysfunction parameters were then related to three concentrations of current U-Hg: (a) low $=<10 \mathrm{nmol} \mathrm{Hg} / \mathrm{mmol}$ creatinine; (b) middle $=10-25 \mathrm{nmol} \mathrm{Hg} / \mathrm{mmol}$ creatinine; and (c) high $=>25 \mathrm{nmol} \mathrm{Hg} / \mathrm{mmol}$ creatinine.

The prevalence of abnormal parameters of renal function in the subgroups with low, middle, and high U-Hg were compared by $\chi^{2}$ test or with Fisher's exact test. Minitab Data Analysis Software, release 7.2, Minitab Inc, USA, was used for all analyses except Fisher's test.

\section{Results}

In the occupationally exposed group median B-Hg was 55 (range 15-299) nmol/l, S-Hg $45(1-255) \mathrm{nmol} /$ 1, and U-Hg $14.3(0.3-46.9) \mathrm{nmol} / \mathrm{mmol}$ creatinine $(25.4(0.5-83.2) \mu \mathrm{g} / \mathrm{g}$ creatinine). These were significantly higher than in the control group where corresponding concentrations were $15(1-65) \mathrm{nmol} / \mathrm{l}$, $4(1-25) \mathrm{nmol} / \mathrm{l}$, and $1.1 \quad(0.03-4.3) \mathrm{nmol} / \mathrm{mmol}$ creatinine $(1.9(0.05-7.6) \mu \mathrm{g} / \mathrm{g}$ creatinine) respectively. In the chloralkali group both $\mathrm{B}-\mathrm{Hg}, \mathrm{S}-\mathrm{Hg}$, and $\mathrm{U}-\mathrm{Hg}$ were significantly related to estimated intensity of exposure but not to duration of exposure. In the control group the strongest predictor for $\mathrm{B}-\mathrm{Hg}$ and $\mathrm{S}-\mathrm{Hg}$ was fish consumption, whereas number of amalgam surfaces was the best predictor for $\mathrm{U}-\mathrm{Hg}$ (see also Langworth et al). ${ }^{21}$

Smoking frequency was $44 \%(39 / 89)$ in the exposed group and $40 \%(30 / 75)$ in the control group. The estimated average weekly alcohol intake (centilitres of liquor) was 14 in the exposed group and 12 in the control group. In neither of the two groups did smoking or alcohol consumption influence the examined parameters.

Figure 1 describes the distribution of the parameters of renal dysfunction in the two groups. There was a tendency (not statistically significant) towards increased urinary NAG activity and decreased excretion of $\beta_{2}$-microglobulin in the mercury exposed group compared with the control group. The group difference in NAG excretion became slightly stronger, and statistically significant $(\mathrm{p}<0.05)$, when workers with diabetes, hyperten- 

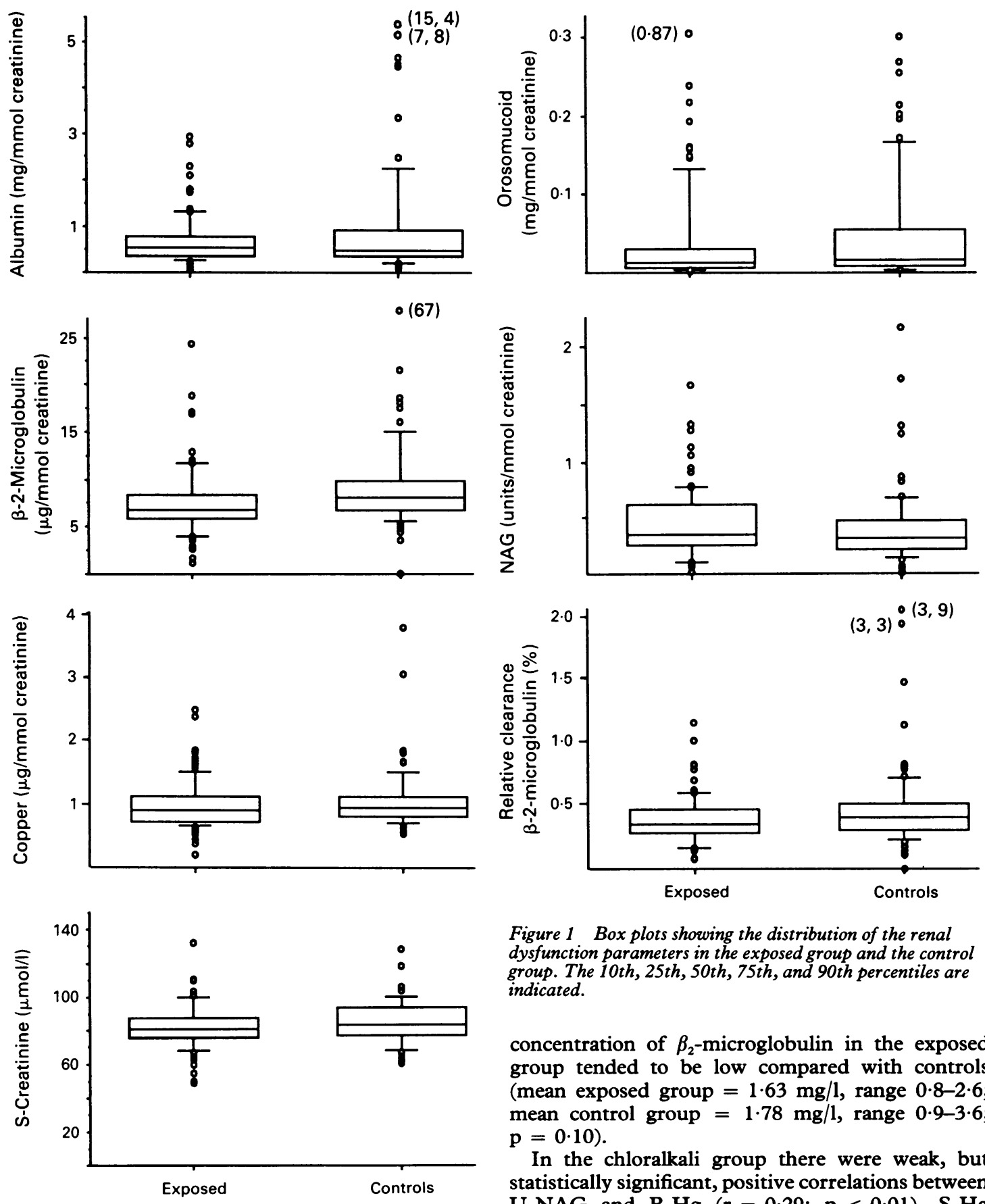

Figure 1 Box plots showing the distribution of the renal dysfunction parameters in the exposed group and the control group. The 10th, 25th, 50th, 75th, and 90th percentiles are indicated.

concentration of $\beta_{2}$-microglobulin in the exposed group tended to be low compared with controls (mean exposed group $=1.63 \mathrm{mg} / \mathrm{l}$, range $0.8-2.6$; mean control group $=1.78 \mathrm{mg} / 1$, range 0.9-3.6; $\mathrm{p}=0 \cdot 10$ ).

In the chloralkali group there were weak, but statistically significant, positive correlations between U-NAG and B-Hg ( $r=0.29 ; \mathrm{p}<0.01)$ S-Hg $(\mathrm{r}=0.26 ; \quad \mathrm{p}<0.05)$, and $\mathrm{U}-\mathrm{Hg} \quad(\mathrm{r}=0.43$;

sion, and history of earlier renal disease were excluded from both groups. None of the other indicators (U-albumin, U-orosomucoid, $\mathrm{U}-\mathrm{Cu}, \mathrm{S}$ creatinine, relative clearance of $\beta_{2}$-microglobulin) differed significantly between the two groups. Serum $\mathrm{p}<0.001$ ). Figure 2 shows the relation between $U-$ $\mathrm{Hg}$ and U-NAG. A significantly higher prevalence of abnormal U-NAG (concentrations above the 90th percentile in the control group) was found in workers with high U-Hg compared with workers with low 


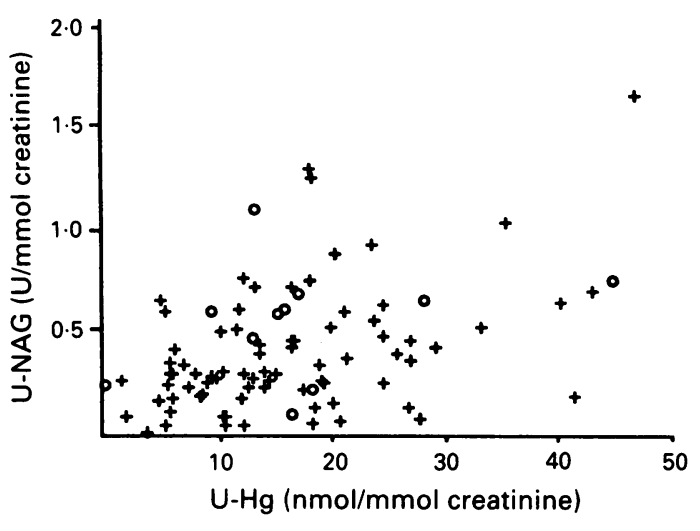

Figure 2 Relation between $U-N A G$ and $U-H g$ in the exposed group. Workers with diabetes, hypertension, or earlier renal disease are indicated by open circles.

U-Hg. A similar tendency was noted for U-orosomucoid (fig 3).

None of the parameters of renal dysfunction was significantly correlated to duration or intensity of exposure. Weak, positive relations were found between age and both U-NAG and U- $\beta_{2}$-microglobulin.

In the control group, there were no significant relations between the parameters of exposure (current $\mathrm{B}-\mathrm{Hg}, \mathrm{S}-\mathrm{Hg}$, and $\mathrm{U}-\mathrm{Hg}$; fish consumption; amalgam burden) and the parameters of renal dysfunction. Age did not influence the parameters studied.

Serum concentrations of immunoglobulins (IgA, IgG, IgM) were normal in both groups (table 1) and we found no relation between immunoglobulin concentrations and the different parameters of exposure. The frequencies of raised titres of serum autoantibodies were low in both groups (table 2). Only one worker exposed to mercury had a weak, positive reaction in the anti GBM ELISA (13 units), and all the controls had negative reactions ( $<10$ units). All responses in the antilaminin ELISA were considered as negative. Average antilaminin ELISA absorbance was 0.0362 (range $0-0.45$ ) in the exposed group and 0.032 (range $0-0.43$ ) in the control group.

\section{Discussion}

Animal studies, case reports, and experiences from highly exposed workers show that high exposure to inorganic mercury may cause renal damage. ${ }^{1}$ Less is known about renal effects after long term exposure to relatively low concentrations of inorganic mercury. Data on dose-response are scant, and many different indicators of renal damage have been used. Which is the most sensitive indicator of renal dysfunction remains to be identified.

It has been suggested that glomerular injury follows an immunological activation, with formation of autoantibodies towards the glomerular basement membrane. The role of mercury in the pathogenesis of this injury has been convincingly shown in animal experiments, ${ }^{5-7} 29$ and some case reports suggest that exposure to mercury may also lead to a glomerulonephritis and nephrotic syndrome in human subjects. Lauwerys and coworkers ${ }^{8}$ reported an increased prevalence of antilaminin antibodies among workers exposed to mercury but this finding was not confirmed in a later study by the same researchers. ${ }^{9}$ Bencko et al ${ }^{30}$ described increased concentrations of serum proteins in workers exposed to mercury vapour compared with unexposed controls, but details concerning mercury concentrations in blood and urine were lacking in this report.

Increased excretion of serum proteins and of tubular enzymes are often used as indicators of renal injury, and the strategy of screening is discussed in two recent reviews. ${ }^{3132}$ Buchet et al ${ }^{14}$ described increased urinary excretion of large proteins (albumin and transferrin) in chloralkali workers with $\mathrm{U}-\mathrm{Hg}$ above $50 \mu \mathrm{g} / \mathrm{g}$ creatinine. The authors proposed a urinary biological threshold limit of $50 \mu \mathrm{g}$ $\mathrm{Hg} / \mathrm{g}$ creatinine $(28.4 \mathrm{nmol} / \mathrm{mmol}$ creatinine), and

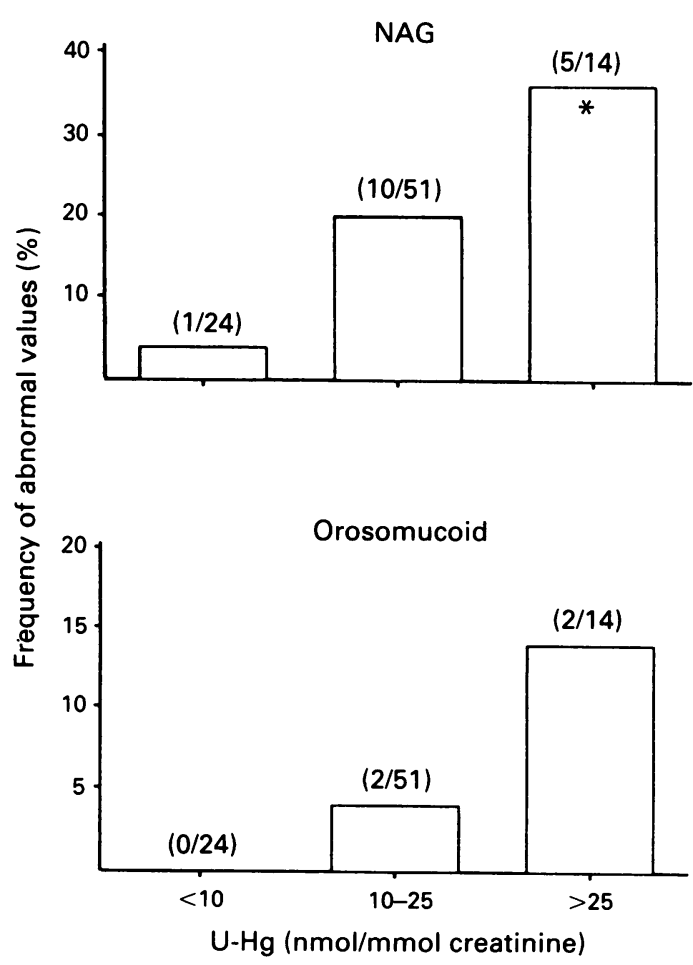

Figure 3 Association between $\mathrm{U}-\mathrm{Hg}$ and frequency of abnormal values of $U-N A G$ and $U$-orosomucoid in the exposed group. * Significantly higher frequency $(p<0.05)$ than that of the "low" class. 
Table 1 Serum immunoglobulin concentrations in exposed and control groups

\begin{tabular}{lcccc}
\hline & \multicolumn{3}{l}{ Immunoglobulin concentrations $(\mathrm{g} / \mathrm{l})$} \\
\cline { 2 - 5 } & Exposed $(n=89)$ & & \multicolumn{2}{c}{ Controls $(n=75)$} \\
\cline { 2 - 5 } \cline { 4 - 5 } & Mean & $S D$ & Mean & $S D$ \\
\hline IgA & 3.2 & 1.5 & 3.6 & 1.4 \\
IgG & 13.7 & 5.3 & 14.7 & 5.2 \\
IgM & 1.8 & 0.8 & 2.0 & 0.8 \\
\hline
\end{tabular}

this proposal was supported in a later study ${ }^{18}$ in which both renal and central nervous system effects were examined. By contrast, Stonard $e t a l^{17}$ did not find any relation between exposure to mercury and the concentration of albumin in urine at a mean $\mathrm{U}$ $\mathrm{Hg}$ of about $67 \mu \mathrm{g} / \mathrm{g}$ creatinine $(38.1 \mathrm{nmol} / \mathrm{mmol}$ creatinine). Neither did Piikivi and Ruokonen ${ }^{33}$ find any increase in urinary albumin among a group of 60 Finnish chloralkali workers with a mean $\mathrm{U}-\mathrm{Hg}$ of $10.1 \mathrm{nmol} / \mathrm{mmol}$ creatinine $(17.8 \mu \mathrm{g} / \mathrm{g}$ creatinine $)$.

Increased excretion of smaller proteins such as orosomucoid, $\beta_{2}$-microglobulin, retinol binding protein (RBP), and of different enzymes, has been widely used as an indicator of tubular injury. Elinder et al $^{34}$ reported increased urinary orosomucoid with decreasing tubular reabsorption capacity, and increasing urinary $\beta_{2}$-microglobulin among workers exposed to cadmium. A mercury related increase in urinary orosomucoid, besides increased excretion of large proteins, was reported by Buchet et al. ${ }^{14}$ The authors also described a slight increase of $\beta_{2}$ microglobulin in plasma, without concomitant increase in urinary $\beta_{2}$-microglobulin, and it was proposed that this finding indicated a small reduction of the glomerular filtration rate in the mercury exposed group. Stonard et $a l^{17}$ described normal concentrations of $\beta_{2}$-microglobulin in plasma, but lower $\beta_{2}$-microglobulin excretion in the mercury exposed group than in the control group. This was interpreted as possible degradation of the protein in urine, enhanced by release of proteases from

Table 2 Serum autoantibody titres to different tissue antigens, determined by indirect immunofluorescence (number of subjects with titres $\geqslant 1 / 10$ )

\begin{tabular}{|c|c|c|c|c|c|c|}
\hline \multirow{3}{*}{$\begin{array}{l}\text { Tissue } \\
\text { specificity }\end{array}$} & \multicolumn{6}{|c|}{ Serum titres } \\
\hline & \multicolumn{3}{|c|}{$\begin{array}{l}\text { Exposed group } \\
(n=89)\end{array}$} & \multicolumn{3}{|c|}{$\begin{array}{l}\text { Control group } \\
(n=75)\end{array}$} \\
\hline & $1 / 10$ & $1 / 25$ & $\geqslant 1 / 100$ & $1 / 10$ & $1 / 25$ & $\geqslant 1 / 100$ \\
\hline $\begin{array}{l}\text { Reticulin } \\
\text { Smooth muscle } \\
\text { Parietal cells } \\
\text { Mitochondria } \\
\text { ANA (nuclear) } \\
\text { Glomeruli }\end{array}$ & $\begin{array}{l}0 \\
0 \\
2 \\
0 \\
2 \\
1\end{array}$ & $\begin{array}{l}0 \\
1 \\
0 \\
0 \\
1 \\
0\end{array}$ & $\begin{array}{l}1 \\
0 \\
0 \\
0 \\
2 \\
0\end{array}$ & $\begin{array}{l}1 \\
1 \\
0 \\
1 \\
0 \\
0\end{array}$ & $\begin{array}{l}0 \\
0 \\
1 \\
2 \\
0 \\
0\end{array}$ & $\begin{array}{l}0 \\
0 \\
0 \\
0 \\
4 \\
0\end{array}$ \\
\hline
\end{tabular}

damaged tubular cells. The authors reported normal concentrations of orosomucoid in urine, and lack of relations between urinary $\beta_{2}$-microglobulin, orosomucoid, and different exposure parameters.

In a study by Roels et al ${ }^{18}$ slight tubular effects were detected as shown by an increased urinary excretion of RBP in workers exposed to mercury. Bernard and coworkers ${ }^{35}$ showed that increased excretion of RBP is a sensitive indicator of early tubular damage, and RBP was suggested to show a close correlation to $\beta_{2}$-microglobulin. The authors also pointed out that RBP is more stable than $\beta_{2}-$ microglobulin in urine samples with low $\mathrm{pH}(<5 \cdot 5)$.

The value of urinary enzymes as indicators of renal tubular damage has been discussed in several reports. ${ }^{151631323637}$ In the screening for effects of mercury on tubules, the enzymes mostly used have been $\beta$-galactosidase, NAG, and $\gamma$-glutamyl transferase $(\gamma-\mathrm{GT})$. The activity of $\beta$-galactosidase in urine has been related to exposure to mercury at $\mathrm{U}$ $\mathrm{Hg}$ of about $50 \mu \mathrm{g} / \mathrm{g}$ creatinine or more by Buchet $e t$ $a l^{14}$ and by Roels et al. ${ }^{18}$ Increased excretion of NAG and $\gamma-G T$ is described by Stonard $e t a^{17}$ at a mean $\mathrm{U}-\mathrm{Hg}$ above $100 \mu \mathrm{g} / \mathrm{g}$ creatinine $(56.8 \mathrm{nmol} / \mathrm{mmol}$ creatinine). Himeno et al ${ }^{19}$ described increased urinary NAG activity at a U-Hg above $140 \mu \mathrm{g} / \mathrm{g}$ creatinine $(79.5 \mathrm{nmol} / \mathrm{mmol}$ creatinine).

In the present study we analysed three urinary proteins (albumin, orosomucoid, and $\beta_{2}$ microglobulin) of different molecular sizes, and one tubular lysosomal enzyme (NAG). The purpose was to discriminate between glomerular and tubular dysfunction. ${ }^{38}$ Measurements of $\beta_{2}$-microglobulin and creatinine in both serum and urine made it possible to calculate the relative clearance of $\beta_{2}$ microglobulin, which is considered as a sensitive measure of tubular function. ${ }^{24}$ Serum concentration of creatinine is often used as a screening tool for glomerular dysfunction in clinical practice. SCreatinine does not, however, increase until the glomerular filtration rate is substantially reduced, and is therefore considered as an unsensitive indicator of glomerular damage. ${ }^{39}$ Increased excretion of copper and a positive relation between $\mathrm{U}-\mathrm{Cu}$ and $U-\beta_{2}$ have been found in workers exposed to cadmium, and $\mathrm{U}-\mathrm{Cu}$ has been proposed as an indicator of tubular dysfunction. ${ }^{4041}$

The finding of normal excretion of albumin in the mercury exposed group does not imply any effect of mercury on glomerular filtration of albumin at the current exposure levels and the lack of raised titres of serum autoantibodies to glomerular structures (both antiglomerular, anti-GBM and antilaminin) argues against the development of a mercury induced glomerulonephritis at the present degree of exposure to mercury. In earlier studies, increased proteinuria has been found at much higher exposure to mercury. ${ }^{2141842}$ 
In accordance with Stonard et $a l^{17}$ we found slightly decreased urinary concentrations of $\beta_{2}$ microglobulin in the exposed group compared with the control group, which may be explained by protein degradation due to release of proteases from injured tubular cells. This finding, together with relatively low serum concentrations of $\beta_{2}$ microglobulin in the exposed workers does not support the previously stated hypothesis of Buchet et al..$^{14}$ The low excretion of $\beta_{2}$-microglobulin together with normal excretion of orosomucoid, copper, and normal relative clearance of $\beta_{2}$-microglobulin argues against a significant effect of mercury on the reabsorbing function of proximal tubules at the present levels of exposure.

Nevertheless, the slight increase in urinary NAG activity among the chloralkali workers combined with the positive relation between $\mathrm{U}-\mathrm{Hg}$ and $\mathrm{U}$ NAG indicates a slight tubular cell damage, probably due to exposure to mercury. The tendency to higher frequencies of increased U-NAG and U-orosomucoid among workers with high $\mathrm{U}-\mathrm{Hg}$ (compared to those with low U-Hg; fig 3) strengthens this conclusion. The relation between $\mathrm{U}$-orosomucoid and $\mathrm{U}-\mathrm{Hg}$ was insignificant, however, and the linear relation between U-NAG and U-Hg was rather weak (fig 2). This is probably explained by the relatively low current $\mathrm{U}-\mathrm{Hg}$ found in the exposed group (range $0-47 \mathrm{nmol} / \mathrm{mmol}$ creatinine $=0-83 \mu \mathrm{g} / \mathrm{g}$ creatinine). As stated, Stonard et $a l^{17}$ reported raised excretion of NAG and $\gamma-\mathrm{GT}$ at $\mathrm{U}-\mathrm{Hg}$ concentrations above $100 \mu \mathrm{g} / \mathrm{g}$ creatinine, and Himeno et al ${ }^{19}$ described a rise in urinary NAG at $\mathrm{U}-\mathrm{Hg}$ concentrations above $140 \mu \mathrm{g} / \mathrm{g}$ creatinine.

Both the group difference in U-NAG and the doseeffect relation between $\mathrm{U}-\mathrm{Hg}$ and U-NAG in the exposed group became somewhat stronger when workers with hypertension, diabetes, and history of earlier renal disease were excluded. Several studies show that U-NAG may be raised in these conditions, ${ }^{43-45}$ so it seems reasonable to exclude workers with such diseases from the calculations (especially if the diseases are uncontrolled).

In the control group signs of glomerular or tubular dysfunction did not correlate with the different exposure indicators. The lack of correlation between amalgam burden and renal dysfunction implies no renal effect of dental amalgam, something that, based on animal experiments, has recently been suggested. ${ }^{46}$ Neither was exposure to methylmercury, estimated as weekly fish consumption, correlated with the parameters of renal dysfunction. Methylmercury is not known to cause renal effects, but background exposure to methylmercury (that is, contaminated fish) may disturb biological monitoring of exposure to inorganic mercury. ${ }^{21}$ Also, a demethylation of mercury has recently been reported in animal organs. ${ }^{47}$

Our finding of normal concentrations of serum immunoglobulins in both groups contradicts the findings of Bencko et al. ${ }^{30}$ This, together with the normal titres of serum autoantibodies, argues against a mercury induced effect on human lymphocytes at the present exposure levels. The possible immunological effects on human subjects of exposure to mercury need further study.

In conclusion, we found no evidence of glomerular damage or defects in tubular reabsorption at the present low exposure to inorganic mercury. Nevertheless, the results indicate a slight tubular cell damage in the group occupationally exposed to mercury. The relation between U-NAG and current $\mathrm{U}-\mathrm{Hg}$ together with the absence of influence (on UNAG) from a cumulative exposure indicator such as duration of exposure suggest that this is predominantly an acute tubular effect, possibly of toxic aetiology. Altogether, this study, in accordance with earlier reports, shows that chronic low exposure to inorganic mercury can cause subclinical signs of nephrotoxicity. $\mathrm{N}$-acetyl- $\beta$-D-glucosaminidase is established as one of the most sensitive indicators of proceeding renal tubular injury.

We thank all personnel at the companies' health care units for excellent collaboration, Lennart Gustafsson for statistical advices, and Kent Wrangskogh for general scientific support. Chemical analyses were made by Kerstin Roxström and Siw Siljerud (mercury), Birgit Åkerlund (protein), Gabriela Balodis (NAG), and Vitauts Lidums (copper in urine) and their help is appreciated. Financial support has been obtained from the Swedish Work Environment Fund.

Requests for reprints to: S Langworth, Department of Occupational Medicine, Huddinge Hospital, S-141 86 Huddinge, Sweden.

1 Berlin M. Mercury. In: Friberg L, Nordberg GF, Vouk VB, eds. Handbook on the toxicology of metals, Vol II. Amsterdam: Elsevier, 1986:387-445.

2 Kazantzis G, Schiller FR, Asscher AW, Drew RB. Albuminuria and the nephrotic syndrome following exposure to mercury and its compounds. $O J M e d$ 1962;31:403-18.

3 Becker C, Becker E, Maher J, Schreiner G. Nephrotic syndrome after contact with mercury. Arch Intern Med 1962;110: 178-86.

4 Strunge $P$. Nephrotic syndrome caused by a seed disinfectant. J Occup Med 1970;12:178-9.

5 Sapin C, Druet E, Druet $\vec{P}$. Induction of antiglomerular basement membrane antibodies in brown Norway rat by mercuric chloride. Clin Exp Immunol 1977;28:173-9.

6 Weening J, Grond J, van der Top D, Hoedemaeker J. Identification of the nuclear antigen involved in mercury-induced glomerulopathy in the rat. Invest Cell Pathol 1980;3:129-34.

7 Hultman P, Eneström S. Mercury induced B-cell activation and antinuclear antibodies in mice. J Clin Lab Immunol 1989; 28:143-50.

8 Lauwerys RL, Bernard AM, Roels HR, Buchet JP, Gennart JP, Mahieu P, Foidart JM. Anti-laminin antibodies in workers exposed to mercury vapour. Toxicol Lett 1983;17:113-6.

9 Bernard AM, Roels HR, Foidart JM, Lauwerys RL. Search for anti-laminin antibodies in the serum of workers exposed to cadmium, mercury vapour or lead. Int Arch Occup Environ Health 1987;59:303-9. 
10 Barnes J, McDowell EMJ, Flamenbaum W, Trump B. Studies on the pathophysiology of acute renal failure. IV. Protective effect of dithiothreitol following administration of mercuric chloride in the rat. Virchows Arch $[B]$ 1980;32:201-32.

11 Barnes J, McDowell EMJ, Flamenbaum W, Trump B. Studies on the pathophysiology of acute renal failure. V. Effect of chronic saline loading on the progression of proximal tubular injury and functional impairment following administration of mercuric chloride in the rat. Virchows Arch $[B]$ 1980;32: 233-60.

12 Foa V, Caimi L, Amante L, Antonini C, Gattinoni A, Tettamanti G, Lombardo A, Giuliani A. Patterns of some lysosomal enzymes in the plasma and of proteins in urine of workers exposed to inorganic mercury. Int Arch Occup Environ Health 1976;37:115-24.

13 Schaller K, Gonzales J, Thurauf J, Schiele R. Fruherkennung von Nierenschäden bei beruflich gegenuber Blei, Quecksilber und Cadmium exponierten Personen. Zentralbl Bakteriol Microbiol Hyg : $B$ : 1980;171:320-35.

14 Buchet JP, Roels H, Bernard A, Lauwerys R. Assessment of renal function of workers exposed to inorganic lead, cadmium or mercury vapor. $J$ Occup Med 1980;22:741-50.

15 Morgan $\mathrm{D}$. Assessment of renal tubular function and damage and their clinical significance. Ann Clin Biochem 1982;19: 307-13.

16 Price R. Urinary enzymes, nephrotoxicity and renal disease. Toxicology 1982;23:99-134.

17 Stonard MD, Chater BV, Duffield DP, Nevitt AL, O'Sullivan IJ, Steel GT. An evaluation of renal function in workers occupationally exposed to mercury vapour. Int Arch Occup Environ Health 1983;52:177-89.

18 Roels H, Gennart JP, Lauwerys R, Buchet JP, Malchaire J, Bernard A. Surveillance of workers exposed to mercury vapour: Validation of a previously proposed biological threshold limit value for mercury concentration in urine. Am J Ind Med 1985;7:45-71.

19 Himeno S, Watanabe C, Suzuki T. Urinary biochemical changes in workers exposed to mercury vapor. Ind Health 1986;24: 151-5.

20 Barregård L, Hultberg B, Schütz A, Sällsten G. Enzymuria in workers exposed to inorganic mercury. Int Arch Occup Environ Health 1988;61:65-9.

21 Langworth S, Elinder C-G, Göthe C-J, Vesterberg O. Biological monitoring of environmental and occupational exposure to mercury. Int Arch Occup Environ Health 1991;63:161-7.

22 Vesterberg $O$. Quantification of albumine in urine by a new method: zone immuno-electrophoresis assay (ZIA). Clin Chim Acto 1981;113:305-10.

23 Maruhn D. Rapid colorimetric assay of $\beta$-galactosidase and Nacetyl- $\beta$-glucosaminidase in human urine. Clin Chim Acta 1976;73:453-61.

24 Evrin PE, Wibell L. The serum levels and urinary excretion of $\beta_{2}$-microglobulin in apparently healthy subjects. Scand J Clin Lab Invest 1972;29:69-74.

25 Weller T-H, Coons A. Fluorescent antibody studies with agents of varicella and herpes zoster propagated in vitro. Proc Soc Exp Biol Med 1954;86:789-98.

26 Engvall E, Perlmann P. ELISA. Enzyme-linked immunosorbent assay. Quantitative assay of immunoglobulin G. Immunochemistry 1971;8:871-4.

27 Einarsson Ö, Lindstedt G, Bergström T. A computerized automatic apparatus for determination of mercury in biological samples. J Automat Chm 1984;2:74-9.

28 Vesterberg $O$. Automatic method for quantitation of mercury in blood, plasma and urine. J Biochem Biophys Methods 1991; 23:227-35
29 Druet P, Bernard A, Hirsch F, Weening JJ, Gengoux P, Mahieu $P$, Birkeland S. Immunologically mediated glomerulonephritis induced by heavy metals. Arch Toxicol 1982;50: 187-94.

30 Bencko V, Wagner V, Wagnerova M, Ondrejcak V. Immunological profiles in workers occupationally exposed to inorganic mercury. J Hyg Epidemiol Microbiol Immunol 1990;34:9-15.

31 Bernard A, Lauwerys R. Epidemiological application of early markers of nephrotoxicity. Toxicol Lett 1989;46:293-306.

32 Flynn FV. Assessment of renal function: Selected developments. Clin Biochem 1990;23:49-54.

33 Piikivi L, Ruokonen A: Renal function and long-term low mercury vapour exposure. Arch Environ Health 1989;44: 146-9.

34 Elinder CG, Edling C, Lindberg E, Kàgedal B, Vesterberg $O$. Assessment of renal function in workers previously exposed to cadmium. Br J Ind Med 1985;42:754-60.

35 Bernard A, Vyskocil A, Mahieu P, Lauwerys R. Assessment of urinary retinol-binding protein as an index of proximal tubular injury. Clin Chem 1987;33:775-9.

36 Meyer BR, Fischbein A, Rosenman K, Lerman Y, Drayer D, Reidenberg MM. Increased urinary enzyme excretion in workers exposed to nephrotoxic chemicals. Am J Med 1984; 76:989-98.

37 Vanderlinde RE. Urinary enzyme measurements in the diagnosis of renal disorders. Ann Clin Lab Sci 1981;11:189-201.

38 Peterson PA, Evrin PE. Differentiation of glomerular, tubular, and normal proteinuria: determination of urinary excretion of beta-2-microglobulin, albumin, and total protein. J Clin Invest 1969;48:1189-98.

39 Prescott LF. Assessment of nephrotoxicity. Br J Clin Pharmacol 1982;13:303-11.

40 Nogawa K, Yamada Y, Honda R, Tsuritani I, Kobayashi E, Ishizaki $M$. Copper and zinc levels in serum and urine of cadmium-exposed people with special reference to renal tubular damage. Environ Res 1984;33:29-38.

41 Ohmori K, Ikemi Y, Tozawa T, Koike S, Mori Y, Toda K. Urinary excretion of cadmium, copper and zinc in workers exposed to cadmium. Japan Journal of Industrial Health 1985;27:16-22.

42 Roels H, Lauwerys R, Buchet JP, Bernard A, Barthels A, Oversteyns $M$, Gaussin J. Comparison of renal function and psychomotor performance in workers exposed to elemental mercury. Int Arch Occup Environ Health 1982;50:77-93.

43 Hanseus K, Hultberg B, Isaksson A, Sjöblad S. Plasma and urinary B-hexosaminidase in juvenile diabetes mellitus. Acta Paediatr Scand 1983;72:77-80.

44 Johnston I, Jones N, Scoble J, Yuen C, Price R. The diagnostic value of urinary enzyme measurements in hypertension. Clin Chim Acta 1983;133:317-25.

45 Sherman RL, Drayer DE, Leyland-Jones BR, Reidenberg MM. $\mathrm{N}$-acetyl- $\boldsymbol{\beta}$-glucosaminidase and $\beta_{2}$-microglobulin. Their urinary excretion in patients with renal parenchymal disease. Arch Intern Med 1983;143:1183-5.

46 Vimy M, Boyd N, Hooper D, Lorsheider F. Glomerular filtration impairment by mercury released from dental "silver" fillings in sheep. Physiologist 1990;33:A-94 (abstract).

47 Friberg L, Mottet KN. Accumulation of methylmercury and inorganic mercury in the brain. Biol Trace Elem Res 1989;21:201-6.

Accepted 7 October 1991 